\title{
THE MECHANISM OF GLYCOSURIC DIURESIS IN DIABETIC MAN ${ }^{1}$
}

\author{
By WILLIAM A. BRODSKY,2 S. RAPOPORT, AND CLARK D. WEST \\ (From the Children's Hospital Research Foundation and the Department of Pediatrics, \\ University of Cincinnati College of Medicine, Cincinnati)
}

(Submitted for publication December 14, 1949; accepted, April 24, 1950)

\section{INTRODUCTION}

Although diuresis has long been recognized as one of the important physiologic aberrations of the diabetic state, its exact nature has not been fully explained. Cushny assumed that the unabsorbed sugar in the renal tubule limits the reabsorption of water through offering osmotic resistance. Thus hyperglycemia leads to glycosuria which in turn causes diuresis (1). Other authors have assigned an important role to an increased electrolyte excretion $(2,3)$, while others have implicated the acidosis (4). It would appear that all three mechanisms, glycosuria, salt loss, and acidosis, may contribute to the copious urine flow of diabetic patients.

It is well known that large electrolyte losses may occur in the uncontrolled diabetic patient (5-8), but the mechanism of the losses has been the subject of some disagreement. While Peters and his associates (4) maintained that the dehydrating effect of acidosis per se was more important than the glycosuria, others have stated the reverse to be the case. Hendrix and his co-workers (2) found large losses of inorganic base in depancreatized, non-acidotic dogs, with polyuria and glycosuria, fed large amounts of glucose. Atchley and his colleagues ( 3 ) found in human diabetics deprived of insulin that the initial loss of base was not dependent on ketosis or acidosis, but accompanied the sudden appearance of marked glycosuria.

The interpretation of the foregoing studies is rendered difficult by the consideration that during the development of diabetic acidosis, vomiting, marked dehydration, shock, lowered blood volume, and diminished renal blood flow and glomerular

1 Presented in part before the American Society for Clinical Investigation, Atlantic City, May 4, 1948: Brodsky, W. A., and Rapoport, S., Renal osmotic work during forced diuresis in dehydration in man. The effect of glucose and urea loading. J. Clin. Invest., 1948, 27, 526.

2 National Institutes of Health Postdoctorate Research Fellow. filtration rate $(9,10)$ occur. All of these changes may be expected to affect the rate of diuresis or electrolyte excretion.

The diuretic effects of glucose in large amounts administered to non-diabetic animals was well known to early workers (11-14). They observed that the concentration of sugar in the urine decreased as the urine flow increased. At the same time the rate of excretion of sugar was increased along with urine flow. Conway (15) produced hyperglycemia in rabbits by injections of glucose and pointed out that the volume of urine was more important than the plasma level in determining the output of sugar. He confirmed Cushny's observation that the concentration of sugar in the urine fell as the urine flow increased. He attempted to describe the diuresis quantitatively by means of an empirically derived formula, $\sqrt{\mathrm{V}}$ $\left(C_{u}-C_{B}\right)=K$, where $V$ was the minute volume of urine, and $C_{n}$ and $C_{B}$ the concentrations of glucose in the urine and blood. The formula implied that a function of the urinary volume was inversely related to the concentration of glucose in the urine: The formula was in rough agreement with the experimental observations. However, a large variation in the $\mathrm{K}$ value was obtained, leading one to suspect that variables other than the glucose concentration alone were involved in the production of the urine volume.

The purpose of the present study was to separate the effects of glycosuria from those of acidosis, by means of glucose loading in non-acidotic diabetic subjects under hydropenic conditions which would provide a reproducible level of urine flow. It has been found, in hydropenic diuresis of nondiabetic subjects, that the total amount of solutes in the urine, rather than that of any single constituent, determines the urine flow (16-18). It appeared of interest to determine whether diabetic subjects behave in the same fashion and whether the effect of glucose is specific or the same as that of other solutes. 


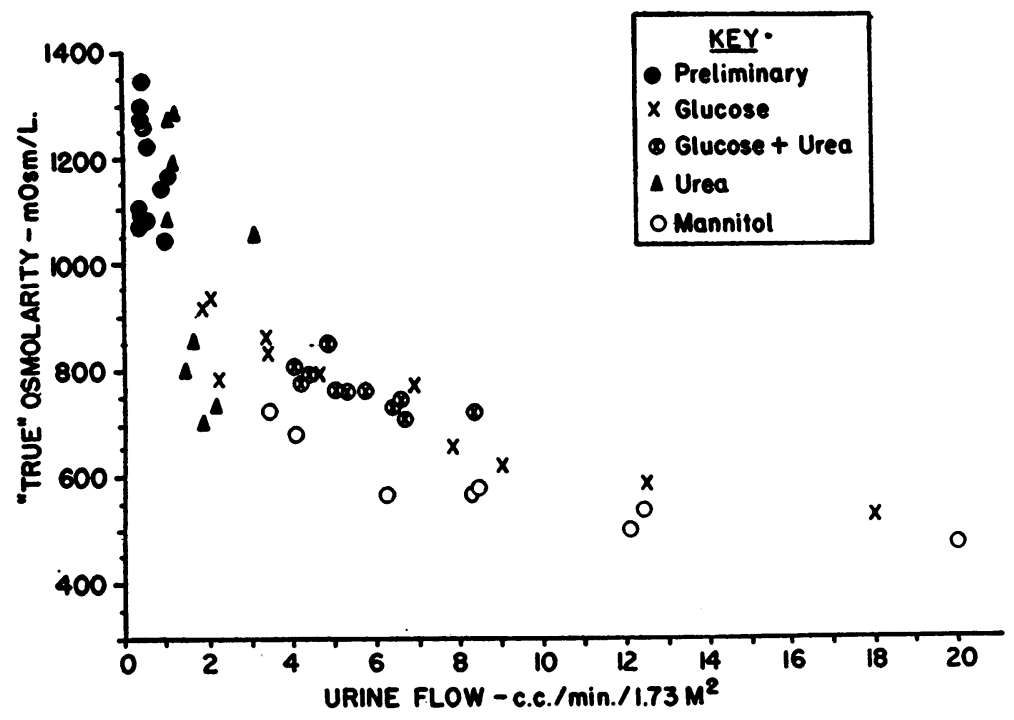

Fig. 1. "True" Osmolarity vs. Urine Flow in Diabetic Subjects

\section{MATERIALS AND METHODS}

The subjects of the present study were three male patients, 13 to 15 years of age, with uncomplicated diabetes mellitus. They had abstained from food and drink for 16 hours preceding the test and omitted the morning dose of insulin. After two or three preliminary periods of urine collection, they received, by mouth or vein, glucose, mannitol, or urea in concentrated solution in dosages of $400-1,100$ milliosmoles per 1.73 square meters of body surface. In two tests, both glucose and urea were administered. In all, five tests comprising $\mathbf{5 5}$ collection periods were performed. Forty-three of the periods were collected during solute loading.

Blood and urine were collected at timed intervals and were analyzed for the loading solute, sodium, potassium, chloride, phosphate, urea and in some instances, sulfate. The concentration of total solutes in the urine was determined from the freezing point and the "true total osmolarity" was calculated as described elsewhere (18). The analytical techniques have been described in previous papers (18).

\section{RESULTS}

Figure 1 presents, for 55 periods, a plot of the values of total osmolarity versus flow. It can be seen that the urine flow increased greatly during loading and that the data followed a definite pattern independent of the type of loading solute over the entire range of flows from $0.33-20.0 \mathrm{cc}$. per minute. With increasing flow, the osmolarity fell at first sharply and then more slowly, apparently approaching a fixed value in an asymptotic manner. The pattern of osmolarity versus flow was prac- tically identical to that of non-diabetic subjects during osmotic diuresis (18). The failure of two subjects to reach minimal rates of urine flow in pre-loading periods may be explained on the basis of hyperglycemia and glycosuria with mild forced diuresis from glucose loading of endogenous origin.

The curve for urinary osmolarity versus load is

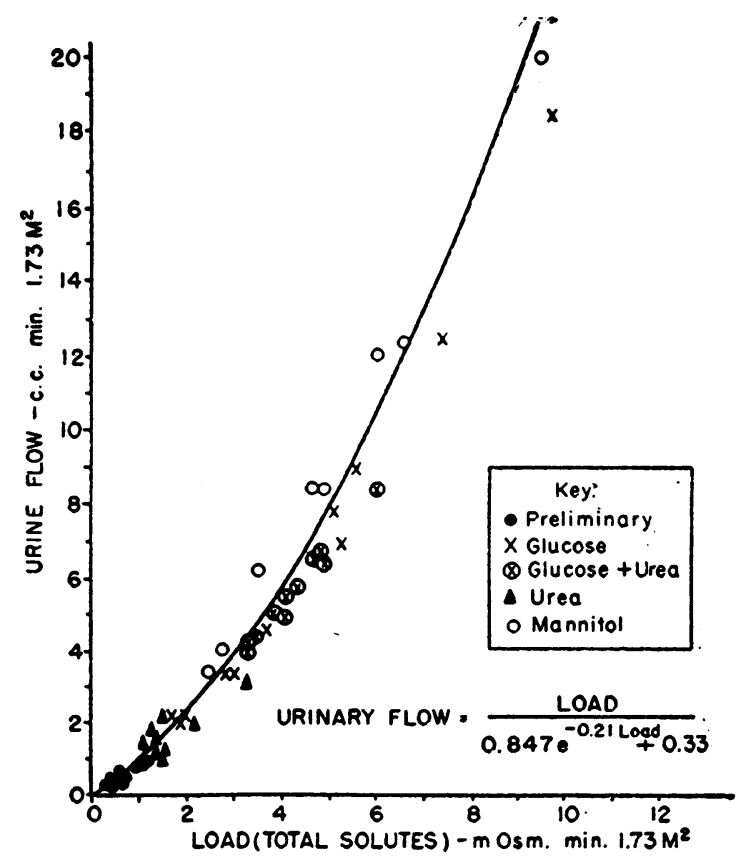

Fig. 2. Urine Flow vs. Load (Total Solutes) in Diabetic Subjects 


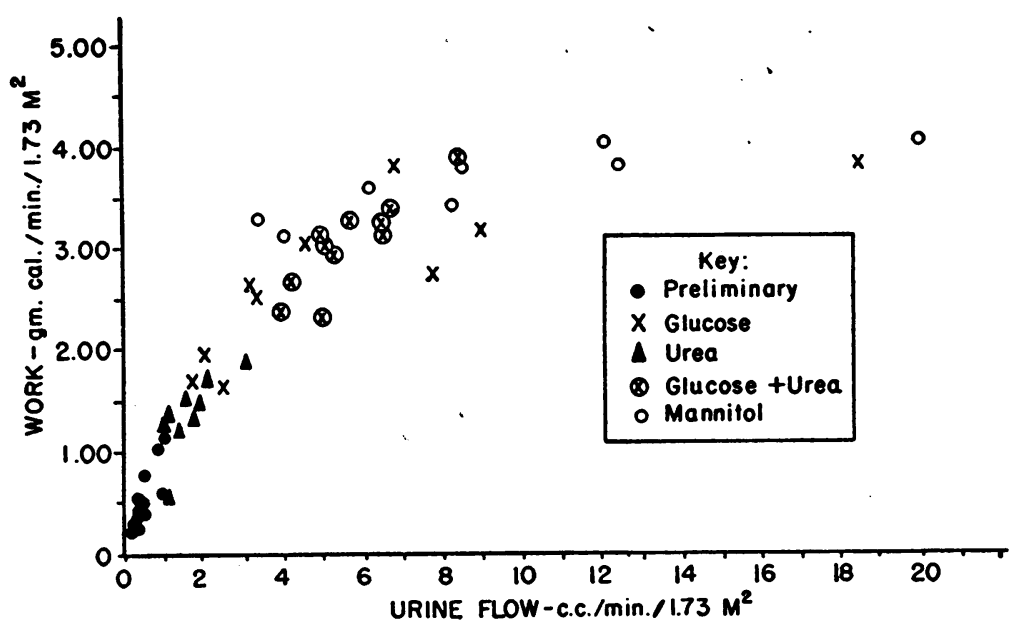

Fig. 3. Ideal Total Work vs. Urine Flow

practically identical to Figure 1 and is therefore omitted from the presentation.

Figure 2 presents a plot of the values of urinary flow versus load. The term "solute load" refers to the rate of minute excretion of all solutes, and is obtained by multiplying the true total osmolarity by the urine flow. The figure contains the theoretical line derived previously (18) and it may be seen that the data fall about the line in a satisfactory manner. The predictable pattern into which the data fall indicates that urine flow is dependent upon the amount of solutes excreted per unit of time-i.e., the total solute load (18).

The flow-load relationship clearly shows that diabetic polyuria is not dependent upon any spe- cific effect of glucose. The rate and pattern of urinary flow in the diabetic patient is identical to that of non-diabetic subjects during solute loading. Furthermore, the diuretic response in the diabetic as well as in the non-diabetic, is a quantitatively reproducible phenomenon.

\section{Renal osmotic work}

The limitations and uncertainties in the application of calculations of the thermodynamic work are well known and have been discussed in detail previously $(19,20)$. Suffice it to say here that even though osmotic work is but a small fraction of the total energy consumption of the kidney, a rather constant and reproducible value of work

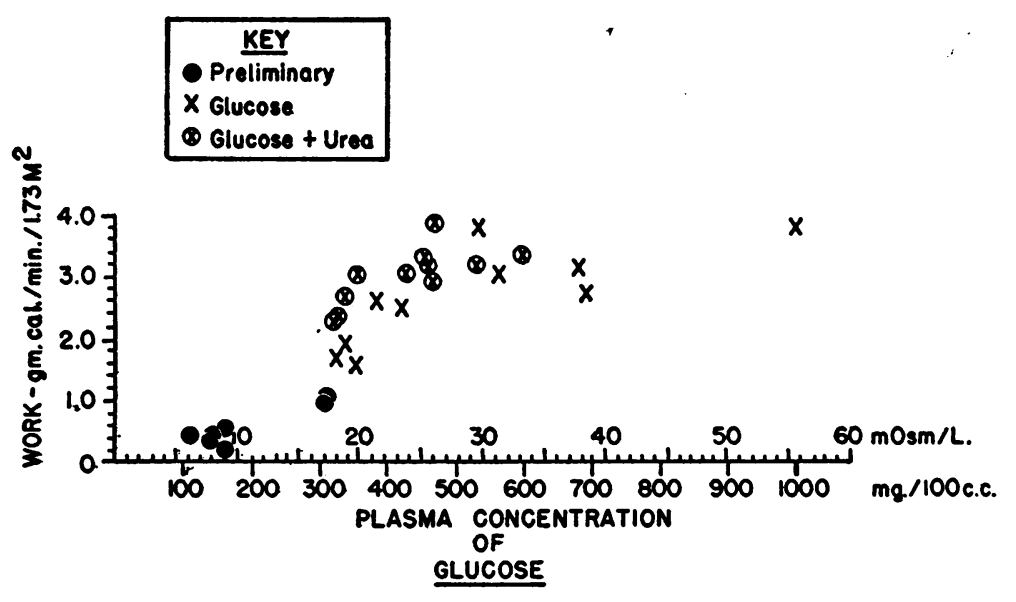

Fig. 4. Ideal Total Work vs. Plasma Concentration of Glucose

Plasma concentration is expressed both in milliosmoles per liter and milligrams per $100 \mathrm{cc}$. of plasma. 
TABLE I

Urine flow and solute concentrations in plasma and urine during osmotic diuresis in diabetic subjects All concentrations are expressed as milliosmols per liter

J.F. 13 yrs. $36.5 \mathrm{~kg}$. S.A., $1.20 \mathrm{M}^{2}$. Glucose (oral and I.V.) and Urea (oral).

\begin{tabular}{|c|c|c|c|c|c|c|c|c|c|c|}
\hline $\begin{array}{c}\text { Period No. } \\
\text { and } \\
\text { Specimen }\end{array}$ & $\begin{array}{c}\text { Concurrent } \\
\text { time }\end{array}$ & $\begin{array}{c}\text { Urine } \\
\text { volume }\end{array}$ & Glucose & Urea & $\mathrm{Na}$ & $\mathbf{K}$ & $\mathrm{Cl}$ & PO4 & $\begin{array}{c}\text { Sum } \\
\text { solutes } \\
\text { deter. }\end{array}$ & $\begin{array}{c}\text { Total } \\
\text { osmolarity } \\
\text { calc. }\end{array}$ \\
\hline P-2 & -95 to -65 & 0.36 & 1.0 & 354.5 & 210.0 & 189.7 & 232.2 & 40.6 & 1028 & 1275 \\
\hline P-3 & $\begin{array}{l}-65 \text { to }-35 \\
-65\end{array}$ & 0.44 & $\begin{array}{l}0.8 \\
7.7^{*}\end{array}$ & $\begin{array}{r}360.5 \\
6.4\end{array}$ & 240.0 & 195.0 & 231.3 & 38.7 & $\begin{array}{r}1066 \\
14.1\end{array}$ & 1260 \\
\hline P-4 & $\begin{array}{l}-35 \text { to }-5 \\
-7\end{array}$ & 0.40 & $\begin{array}{l}0.6 \\
6.1^{*}\end{array}$ & 356.0 & 225.0 & 210.0 & 245.1 & 36.8 & $\begin{array}{r}1074 \\
6.1\end{array}$ & 1347 \\
\hline
\end{tabular}

0 to 1 Glucose (oral), $799 \mathrm{mOsm} / 1.73 \mathrm{M}^{2}$ in $70 \mathrm{cc}$. lemon juice

1 to $3 \mathrm{I}$.V. injection $50 \%$ glucose $200 \mathrm{mOsm} / 1.73 \mathrm{M}^{2}$

\begin{tabular}{|c|c|c|c|c|c|c|c|c|c|c|c|}
\hline 1 & $\begin{array}{l}\mathbf{U} \\
\mathbf{P}\end{array}$ & $\begin{array}{c}-5 \text { to } \\
10\end{array}+25$ & 2.20 & $\begin{array}{c}253.0 \\
19.4^{*}\end{array}$ & $\begin{array}{r}205.5 \\
6.9\end{array}$ & 70.0 & 55.2 & 71.6 & 6.2 & $\begin{array}{c}662 \\
26.3\end{array}$ & 788 \\
\hline 2 & $\stackrel{\mathrm{U}}{\mathbf{P}}$ & $\begin{array}{l}25 \text { to } \\
25\end{array}$ & 2.01 & $\begin{array}{c}422.3 \\
18.6^{*}\end{array}$ & $\begin{array}{r}233.0 \\
6.9\end{array}$ & 60.0 & 45.0 & 50.4 & 9.1 & $\begin{array}{l}820 \\
25.4\end{array}$ & 934 \\
\hline 3 & $\stackrel{\mathrm{U}}{\mathbf{P}}$ & $\begin{array}{c}55 \text { to } 85 \\
55\end{array}$ & 1.81 & $\begin{array}{c}450.0 \\
17.8^{*}\end{array}$ & $\begin{array}{r}200.0 \\
7.5\end{array}$ & 60.0 & 31.3 & 45.2 & 6.6 & $\begin{array}{l}793 \\
25.3\end{array}$ & 920 \\
\hline 4 & $\stackrel{\mathrm{U}}{\mathrm{P}}$ & $\begin{array}{l}85 \text { to } 115 \\
85\end{array}$ & 3.36 & $\begin{array}{c}426.8 \\
21.3^{*}\end{array}$ & $\begin{array}{r}173.0 \\
7.5\end{array}$ & 70.0 & 26.8 & 44.2 & 4.8 & $\begin{array}{l}746 \\
28.8\end{array}$ & 868 \\
\hline 5 & $\stackrel{\mathrm{U}}{\mathrm{P}}$ & $\begin{array}{c}115 \text { to } 145 \\
115\end{array}$ & 3.41 & $\begin{array}{c}463.8 \\
23.2^{*}\end{array}$ & $\begin{array}{r}140.0 \\
8.0\end{array}$ & 67.5 & 18.2 & 41.8 & 3.9 & $\begin{array}{c}735 \\
28.2\end{array}$ & 836 \\
\hline 6 & $\mathbf{U}$ & 145 to 175 & 4.65 & 447.0 & 118.5 & 57.5 & 16.8 & 39.2 & 4.8 & 684 & 800 \\
\hline 7 & $\stackrel{\mathrm{U}}{\mathrm{P}}$ & $\begin{array}{c}175 \text { to } 205 \\
194\end{array}$ & 6.87 & $\begin{array}{c}433.5 \\
29.7^{*}\end{array}$ & $\begin{array}{r}100.5 \\
8.5\end{array}$ & $\begin{array}{r}70.0 \\
141.0\end{array}$ & $\begin{array}{r}15.8 \\
6.2\end{array}$ & 45.8 & 4.1 & $\begin{array}{l}670 \\
185.4\end{array}$ & $\begin{array}{l}770 \\
325\end{array}$ \\
\hline
\end{tabular}

198 to 200 Urea (oral), $599 \mathrm{mOsm} / 1.73 \mathrm{M}^{2}$ in $50 \mathrm{cc}$. lemon juice

\begin{tabular}{|c|c|c|c|c|c|c|c|c|c|c|c|}
\hline 8 & $\mathrm{U}$ & 205 to 225 & 6.70 & 405.5 & 90.0 & 80.0 & 13.0 & 51.4 & 3.9 & 644 & 718 \\
\hline 9 & $\stackrel{\mathrm{U}}{\mathrm{P}}$ & $\begin{array}{c}225 \text { to } 245 \\
240\end{array}$ & 5.31 & $\begin{array}{l}381.0 \\
26.0^{*}\end{array}$ & $\begin{array}{r}175.5 \\
17.8\end{array}$ & $\begin{array}{r}75.0 \\
145.0\end{array}$ & $\begin{array}{r}16.8 \\
6.2\end{array}$ & 51.6 & 3.9 & $\begin{array}{l}704 \\
195.0\end{array}$ & $\begin{array}{l}763 \\
338\end{array}$ \\
\hline 10 & $\stackrel{\mathrm{U}}{\mathrm{P}}$ & $\begin{array}{c}245 \text { to } 265 \\
250\end{array}$ & 8.35 & 279.2 & $\begin{array}{r}228.5 \\
21.3\end{array}$ & 77.5 & 19.5 & 54.8 & 4.1 & $\begin{array}{c}664 \\
21.3\end{array}$ & 726 \\
\hline
\end{tabular}

E.H. 15 yrs. $54.3 \mathrm{~kg} . \quad$ S.A., $1.56 \mathrm{M}^{2}$ Urea (oral) and Glucose (oral and I.V.)

\begin{tabular}{ll|c|c|r|r|r|r|r|r|r|r}
\hline $\mathrm{P}-1$ & $\mathrm{U}$ & -97 to -67 & 0.33 & 3.6 & 252.4 & 337.6 & 78.0 & 277.5 & 31.4 & 980 & 1107 \\
& $\mathrm{P}$ & -97 & & $9.0^{*}$ & 6.4 & 140.2 & 4.5 & 111.2 & $1.4 \dagger$ & 273 & 297 \\
$\mathrm{P}-2$ & $\mathrm{U}$ & -67 to -37 & 0.97 & 17.4 & 254.1 & 285.0 & 79.5 & 231.6 & 32.2 & 900 & 1045 \\
\hline
\end{tabular}

0 to 3 Urea (oral), $647 \mathrm{mOsm} / 1.73 \mathrm{M}^{2}$ in $75 \mathrm{cc}$. lemon juice

\begin{tabular}{|c|c|c|c|c|c|c|c|c|c|c|c|}
\hline 2 & $\stackrel{\mathrm{U}}{\mathbf{P}}$ & $\begin{array}{c}23 \text { to } 53 \\
38\end{array}$ & 3.12 & 30.0 & $\begin{array}{r}302.6 \\
10.6\end{array}$ & $\begin{array}{l}262.5 \\
138.0\end{array}$ & $\begin{array}{r}75.2 \\
4.9\end{array}$ & $\begin{array}{l}234.6 \\
107.2\end{array}$ & 17.7 & $\begin{array}{l}923 \\
262\end{array}$ & 1055 \\
\hline 3 & $\stackrel{\mathrm{U}}{\mathrm{P}}$ & $\begin{array}{c}53 \text { to } 83 \\
67\end{array}$ & 1.13 & $\begin{array}{c}8.0 \\
10.0^{*}\end{array}$ & $\begin{array}{r}258.4 \\
11.5\end{array}$ & $\begin{array}{l}225.0 \\
138.0\end{array}$ & $\begin{array}{r}80.0 \\
4.3\end{array}$ & $\begin{array}{l}233.0 \\
109.6\end{array}$ & 21.0 & $\begin{array}{l}825 \\
275\end{array}$ & $\begin{array}{r}1190 \\
298\end{array}$ \\
\hline 4 & $\begin{array}{l}\mathrm{U} \\
\mathbf{P}\end{array}$ & $\begin{array}{l}83 \text { to } 113 \\
98\end{array}$ & 1.99 & $\begin{array}{l}58.5 \\
10.7 *\end{array}$ & $\begin{array}{r}418.2 \\
13.9\end{array}$ & $\begin{array}{l}205.0 \\
136.5\end{array}$ & $\begin{array}{r}63.0 \\
4.6\end{array}$ & $\begin{array}{l}199.6 \\
108.4\end{array}$ & 16.9 & $\begin{array}{l}961 \\
276\end{array}$ & $\begin{array}{r}1084 \\
299\end{array}$ \\
\hline
\end{tabular}

* Determined on whole blood

† Value determined on pooled plasma 
TABLE I-Continued

118 to 119 Glucose (oral), $924 \mathrm{mOsm} / 1.73 \mathrm{M}^{2}$ in $115 \mathrm{cc}$. water 120 to $123 \mathrm{I}$.V. injection $50 \%$ glucose $154 \mathrm{mOsm} / 1.73 \mathrm{M}^{2}$

\begin{tabular}{|c|c|c|c|c|c|c|c|c|c|c|c|}
\hline \multicolumn{2}{|c|}{$\begin{array}{c}\text { Period No. } \\
\text { and } \\
\text { Specimen }\end{array}$} & $\begin{array}{c}\text { Concurrent } \\
\text { time }\end{array}$ & $\begin{array}{c}\text { Urine } \\
\text { volume }\end{array}$ & Glucose & Urea & $\mathbf{N a}$ & $\mathbf{K}$ & $\mathrm{Cl}$ & PO. & $\begin{array}{c}\text { Sum } \\
\text { solutes } \\
\text { deter. }\end{array}$ & $\begin{array}{c}\text { Total } \\
\text { osmolarity } \\
\text { calc. }\end{array}$ \\
\hline 5 & $\underset{\mathbf{P}}{\mathbf{U}}$ & $\begin{array}{c}113 \text { to } 143 \\
128\end{array}$ & 4.31 & $\begin{array}{r}202.6 \\
17.8\end{array}$ & $\begin{array}{r}236.6 \\
15.0\end{array}$ & $\begin{array}{r}95.0 \\
135.8\end{array}$ & $\begin{array}{r}32.5 \\
4.3\end{array}$ & $\begin{array}{r}99.6 \\
107.2\end{array}$ & 6.0 & $\begin{array}{l}672 \\
282\end{array}$ & $\begin{array}{l}792 \\
305\end{array}$ \\
\hline 6 & $\stackrel{\mathrm{U}}{\mathbf{P}}$ & $\begin{array}{c}143 \text { to } 173 \\
157\end{array}$ & 4.04 & $\begin{array}{r}288.6 \\
18.0^{*}\end{array}$ & $\begin{array}{r}225.6 \\
14.4\end{array}$ & $\begin{array}{r}62.5 \\
136.5\end{array}$ & $\begin{array}{r}20.8 \\
4.8\end{array}$ & $\begin{array}{r}73.7 \\
108.8\end{array}$ & 5.0 & $\begin{array}{l}676 \\
284\end{array}$ & $\begin{array}{l}810 \\
307\end{array}$ \\
\hline 7 & $\stackrel{\mathrm{U}}{\mathbf{P}}$ & $\begin{array}{c}173 \text { to } 203 \\
187\end{array}$ & 4.22 & $\begin{array}{c}327.4 \\
18.6^{*}\end{array}$ & $\begin{array}{r}205.7 \\
13.0\end{array}$ & $\begin{array}{r}47.5 \\
132.8\end{array}$ & $\begin{array}{r}16.5 \\
4.4\end{array}$ & $\begin{array}{r}56.9 \\
106.8\end{array}$ & 4.7 & $\begin{array}{l}659 \\
277\end{array}$ & $\begin{array}{l}779 \\
298\end{array}$ \\
\hline 8 & $\underset{\mathrm{P}}{\mathrm{U}}$ & $\begin{array}{c}203 \text { to } 233 \\
218\end{array}$ & 4.92 & $\begin{array}{c}349.6 \\
19.6^{*}\end{array}$ & $\begin{array}{r}188.2 \\
14.1\end{array}$ & $\begin{array}{r}45.0 \\
134.3\end{array}$ & $\begin{array}{r}13.3 \\
4.3\end{array}$ & $\begin{array}{r}49.9 \\
107.2\end{array}$ & 4.3 & $\begin{array}{l}650 \\
281\end{array}$ & $\begin{array}{l}853 \\
303\end{array}$ \\
\hline 9 & $\mathrm{U}$ & $\begin{array}{c}233 \text { to } 263 \\
248\end{array}$ & 5.03 & $\begin{array}{c}366.3 \\
23.9^{*}\end{array}$ & $\begin{array}{r}176.7 \\
14.0\end{array}$ & $\begin{array}{r}40.0 \\
141.7\end{array}$ & $\begin{array}{r}12.5 \\
4.9\end{array}$ & $\begin{array}{r}46.2 \\
108.4\end{array}$ & 3.7 & $\begin{array}{l}645 \\
294\end{array}$ & $\begin{array}{l}766 \\
323\end{array}$ \\
\hline 10 & $\stackrel{\mathrm{U}}{\mathbf{P}}$ & $\begin{array}{c}263 \text { to } 293 \\
278\end{array}$ & 5.70 & $\begin{array}{l}358.0 \\
25.3^{*}\end{array}$ & $\begin{array}{r}171.2 \\
13.4\end{array}$ & $\begin{array}{r}45.0 \\
140.2\end{array}$ & $\begin{array}{r}13.3 \\
4.7\end{array}$ & $\begin{array}{r}47.1 \\
104.8\end{array}$ & 3.7 & $\begin{array}{l}638 \\
290\end{array}$ & $\begin{array}{l}767 \\
320\end{array}$ \\
\hline 11 & $\underset{\mathbf{P}}{\mathbf{U}}$ & $\begin{array}{c}293 \text { to } 323 \\
308\end{array}$ & 6.55 & $\begin{array}{c}330.2 \\
29.5^{*}\end{array}$ & $\begin{array}{r}170.4 \\
14.9\end{array}$ & $\begin{array}{r}47.5 \\
138.0\end{array}$ & $\begin{array}{r}14.8 \\
4.7\end{array}$ & $\begin{array}{r}48.8 \\
107.6\end{array}$ & 3.7 & $\begin{array}{l}615 \\
296\end{array}$ & $\begin{array}{l}740 \\
322\end{array}$ \\
\hline 12 & $\underset{\mathrm{P}}{\mathrm{U}}$ & $\begin{array}{c}323 \text { to } 353 \\
338\end{array}$ & 6.55 & $\begin{array}{c}305.2 \\
25.3^{*}\end{array}$ & $\begin{array}{r}182.3 \\
15.9\end{array}$ & $\begin{array}{r}52.6 \\
141.7\end{array}$ & $\begin{array}{r}20.5 \\
4.8\end{array}$ & $\begin{array}{r}57.2 \\
106.8\end{array}$ & 3.9 & $\begin{array}{l}622 \\
296\end{array}$ & $\begin{array}{l}739 \\
326\end{array}$ \\
\hline
\end{tabular}

J.F. 13 yrs. $36.7 \mathrm{~kg} . \quad$ S.A., $1.20 \mathrm{M}^{2} \quad$ Urea (oral)

\begin{tabular}{|c|c|c|c|c|c|c|c|c|c|c|c|}
\hline P-2 & $\mathbf{U}$ & -94 to -64 & 0.50 & 6.8 & 293.9 & 262.0 & 120.7 & 273.6 & 22.0 & 979 & 1089 \\
\hline P-3 & $\mathrm{U}$ & -64 to -34 & 0.34 & 7.7 & 285.3 & 210.0 & 129.0 & 271.2 & 18.2 & 921 & 1095 \\
\hline$P-4$ & $\begin{array}{l}\mathbf{U} \\
\mathbf{P}\end{array}$ & $\begin{array}{c}-34 \text { to }-4 \\
-8\end{array}$ & 0.32 & $\begin{array}{l}6.8 \\
7.7^{*}\end{array}$ & $\begin{array}{r}288.2 \\
6.4\end{array}$ & 180.0 & 126.0 & 260.4 & 15.1 & $\begin{array}{l}876 \\
14.1\end{array}$ & 1077 \\
\hline
\end{tabular}

\begin{tabular}{|c|c|c|c|c|c|c|c|c|c|c|c|}
\hline 2 & $\mathrm{U}$ & $\begin{array}{c}26 \text { to } 56 \\
43\end{array}$ & 1.41 & $\begin{array}{l}2.2 \\
6.5\end{array}$ & $\begin{array}{r}493.5 \\
14.2\end{array}$ & 67.3 & 60.0 & 115.8 & 3.4 & $\begin{array}{l}742 \\
20.7\end{array}$ & 806 \\
\hline 3 & $\underset{\mathbf{P}}{\mathbf{P}}$ & $\begin{array}{c}56 \text { to } 86 \\
70\end{array}$ & 1.83 & 1.2 & $\begin{array}{r}463.9 \\
19.1\end{array}$ & 30.0 & 45.5 & 77.6 & 1.7 & $\begin{array}{l}620 \\
19.1\end{array}$ & 700 \\
\hline 4 & $\begin{array}{l}\mathbf{U} \\
\mathbf{P}\end{array}$ & $\begin{array}{l}86 \text { to } 116 \\
101\end{array}$ & 2.12 & $\begin{array}{l}0.7 \\
5.8\end{array}$ & $\begin{array}{r}523.5 \\
20.5\end{array}$ & 30.0 & 38.8 & 72.4 & 2.0 & $\begin{array}{c}667 \\
26.3\end{array}$ & 737 \\
\hline 5 & $\begin{array}{l}\mathbf{U} \\
\mathbf{P}\end{array}$ & $\begin{array}{c}116 \text { to } 146 \\
129\end{array}$ & 1.61 & 1.0 & $\begin{array}{r}588.5 \\
20.2\end{array}$ & 35.0 & 42.0 & 83.2 & 2.0 & $\begin{array}{l}752 \\
20.2\end{array}$ & 857 \\
\hline 6 & $\underset{\mathrm{P}}{\mathrm{U}}$ & $\begin{array}{c}146 \text { to } 176 \\
161\end{array}$ & 1.15 & $\begin{array}{l}1.4 \\
6.5^{*}\end{array}$ & $\begin{array}{r}687.4 \\
19.0\end{array}$ & 37.5 & 46.5 & 90.0 & 2.1 & $\begin{array}{l}865 \\
25.5\end{array}$ & 1281 \\
\hline 7 & $\mathrm{U}$ & 176 to 206 & 1.08 & 1.8 & 683.5 & 37.5 & 43.5 & 84.0 & 2.0 & 852 & 1272 \\
\hline \multicolumn{12}{|c|}{ E. H. 16 yrs. $63.6 \mathrm{~kg}}$. \\
\hline P-1 & $\mathbf{U}$ & -83 to -54 & 0.35 & & 37.0 & 598.9 & 97.5 & 174.8 & 129.6 & 1038 & 1299 \\
\hline P-2 & $\begin{array}{l}\mathbf{U} \\
\mathbf{P}\end{array}$ & $\begin{array}{c}-54 \text { to }-16 \\
-18\end{array}$ & 0.55 & & $\begin{array}{r}100.1 \\
12.7\end{array}$ & $\begin{array}{r}535.2 \\
7.2\end{array}$ & $\begin{array}{l}157.5 \\
152.3\end{array}$ & $\begin{array}{r}135.0 \\
4.29\end{array}$ & $\begin{array}{l}141.0 \\
108.4\end{array}$ & $\begin{array}{r}1069 \\
285\end{array}$ & $\begin{array}{r}1227 \\
325\end{array}$ \\
\hline
\end{tabular}

* Determined on whole blood 
TABLE I-Continued

0 to 15 Mannitol (I.V.), $409 \mathrm{mOsm} / 1.73 \mathrm{M}^{2}$

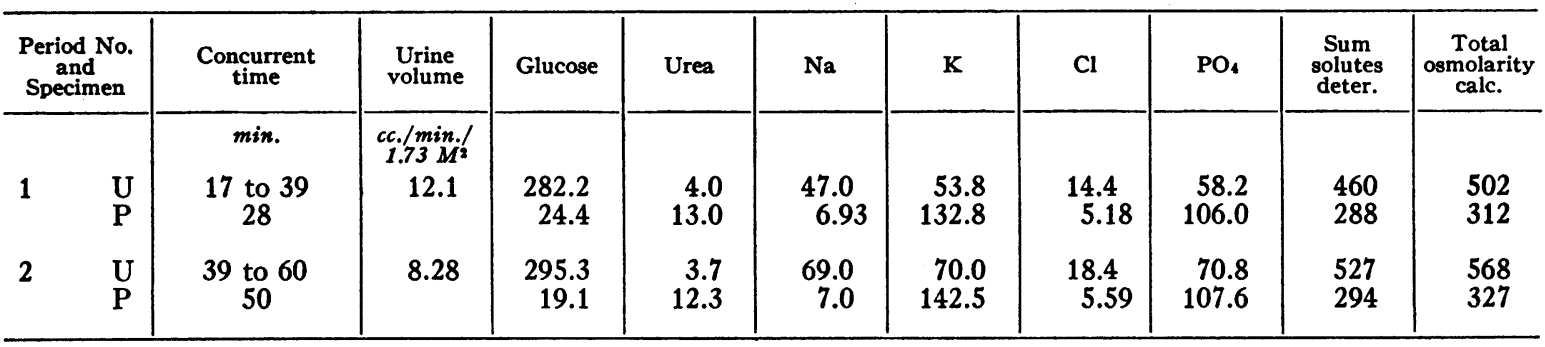

64 to 72 Mannitol (I.V.), $412 \mathrm{mOsm} / 1.73 \mathrm{M}^{2}$

\begin{tabular}{rc|c|r|r|r|r|r|r|r|r|r}
\hline 3 & $\mathrm{U}$ & 74 to 94 & 20.0 & 269.0 & 3.0 & 28.3 & 65.0 & 13.4 & 64.8 & 444 & 477 \\
& $\mathrm{P}$ & 81 & & 43.1 & 11.9 & 7.36 & 130.5 & 4.98 & 101.2 & 299 & 325 \\
4 & $\mathrm{U}$ & 94 to 117 & 12.4 & 307.4 & 2.8 & 43.9 & 65.0 & 17.2 & 65.2 & 502 & 539 \\
& $\mathrm{P}$ & 106 & & 33.2 & 12.6 & 6.57 & 129.8 & 4.71 & 102.8 & 290 & 313 \\
5 & $\mathrm{U}$ & 117 to 139 & 8.45 & 351.9 & 2.8 & 56.7 & 52.5 & 22.0 & 62.8 & 549 & 584 \\
& $\mathrm{P}$ & 129 & & 25.7 & 14.3 & 6.5 & 132.8 & 5.6 & 104.8 & 290 & 315 \\
6 & $\mathrm{U}$ & 139 to 159 & 6.23 & 380.4 & 2.7 & 68.1 & 45.0 & 22.9 & 52.0 & 571 & 567 \\
7 & $\mathrm{U}$ & 159 to 178 & 4.08 & 426.0 & 2.2 & 81.5 & 27.5 & 28.8 & 39.6 & 606 & 682 \\
8 & $\mathrm{U}$ & 178 to 199 & 3.43 & 473.2 & 4.3 & 92.3 & 18.8 & 28.9 & 34.2 & 652 & 727 \\
\hline
\end{tabular}

L. D. 13 yrs. $38.9 \mathrm{~kg}$. S.A., $1.31 \mathrm{M}^{2}$ Glucose (oral and I.V.)

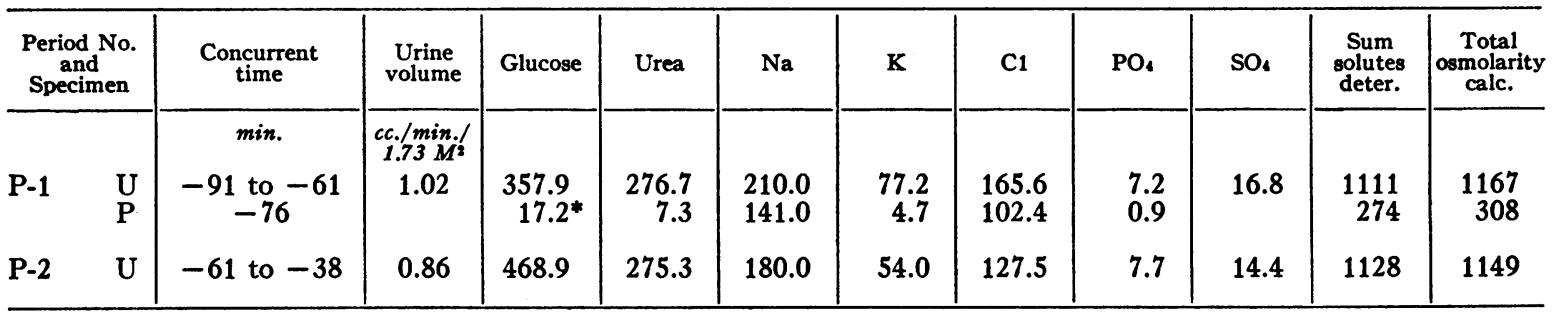

-24 to -23 Glucose (oral), $366 \mathrm{mOsm} / 1.73 \mathrm{M}^{2}$ in $70 \mathrm{cc}$. lemon juice

0 to 4 I.V. injection $50 \%$ glucose $256 \mathrm{mOsm} / 1.73 \mathrm{M}^{2}$ with $50 \mathrm{cc}$. N. saline

\begin{tabular}{|c|c|c|c|c|c|c|c|c|c|c|c|c|}
\hline 1 & $\stackrel{\mathrm{U}}{\mathrm{P}}$ & $\begin{array}{l}5 \text { to } 26 \\
15\end{array}$ & 9.04 & $\begin{array}{r}348.2 \\
38.0\end{array}$ & $\begin{array}{r}61.4 \\
7.3\end{array}$ & $\begin{array}{r}82.5 \\
132.0\end{array}$ & $\begin{array}{r}14.2 \\
5.6\end{array}$ & $\begin{array}{r}58.4 \\
100.0\end{array}$ & $\begin{array}{l}1.4 \\
0.9\end{array}$ & 2.1 & $\begin{array}{l}568 \\
284\end{array}$ & $\begin{array}{l}618 \\
312\end{array}$ \\
\hline 2 & $\stackrel{\mathrm{U}}{\mathrm{P}}$ & $\begin{array}{c}26 \\
37\end{array}$ & 7.79 & $\begin{array}{r}353.8 \\
38.7\end{array}$ & $\begin{array}{r}71.1 \\
8.8\end{array}$ & $\begin{array}{r}92.5 \\
134.0\end{array}$ & $\begin{array}{r}13.5 \\
5.5\end{array}$ & $\begin{array}{r}70.0 \\
100.0\end{array}$ & 1.8 & 2.5 & $\begin{array}{l}605 \\
287\end{array}$ & $\begin{array}{l}660 \\
318\end{array}$ \\
\hline \multicolumn{13}{|c|}{52 to $56 \mathrm{I} . \mathrm{V}$. injection $50 \%$ glucose $476 \mathrm{mOsm} / 1.73 \mathrm{M}^{2}$} \\
\hline 3 & $\begin{array}{l}\mathrm{U} \\
\mathrm{P}\end{array}$ & $\begin{array}{c}58 \text { to } 79 \\
69\end{array}$ & 18.5 & $\begin{array}{r}313.5 \\
55.8\end{array}$ & $\begin{array}{r}31.4 \\
8.8\end{array}$ & $\begin{array}{r}82.5 \\
127.5\end{array}$ & $\begin{array}{r}15.5 \\
5.8\end{array}$ & $\begin{array}{l}59.6 \\
98.0\end{array}$ & 1.0 & 1.8 & $\begin{array}{l}505 \\
296\end{array}$ & $\begin{array}{l}529 \\
323\end{array}$ \\
\hline
\end{tabular}

* Determined on whole blood.

can be obtained under conditions of osmotic loading. Therefore, it would appear justifiable to record calculated work values with all the reservations in mind.

Figure 3 presents, for 50 collection periods, 40 of which were collected during loading, a plot of the values for ideal total work versus urine flow.
It can be seen that work increases sharply to values of 3.0-4.0 gram-calories per minute with increasing urine flows until a flow of $7 \mathrm{cc}$. per minute is reached. Further increases in rate of urine flow resulted in only slight increases in work. In all instances, the loading solute accounted for the bulk of the work. The pattern of work versus 
flow is strongly suggestive of the existence of a maximum capacity or ceiling for performance of osmotic work by the kidney. A practically identical pattern of work-flow has been found in nondiabetic subjects during solute loading (20).

The data for work versus load were almost identical in pattern to those of work versus flow and have been omitted from the presentation.

Given the existence of a biologic maximum for osmotic work, an independence between work and plasma level of loading solute, as well as urine flow and load, would be expected.

Figure 4 presents the relationship between ideal total work and plasma level of glucose. It is evident that increasing the plasma level of glucose beyond 20 milliosmoles per liter (360 mg. per 100 cc.) failed to increase significantly the amount of renal osmotic work. The same relation between work and plasma level of the loading substance was observed in non-diabetic subjects during osmotic diuresis.

\section{Solutes in plasma and urine}

Table I presents the values for concentrations of solutes in the urine and plasma during osmotic diuresis.

The concentrations of the loacing solute in the plasma was increased by about $20-40$ milliosmoles per liter in most instances. In the case of glucose a plasma level of 55.8 milliosmoles per liter was reached. After urea, the plasma level increased from 6.4 to 20.5 milliosmoles per liter. With mannitol, a level of 43.1 milliosmoles per liter was reached.

In the pre-loading periods, the total osmolarity of the plasma ranged from 297-308 milliosmoles per liter with one exceptional value of 325 in the case of patient E. H. After loading, the plasma osmolarity increased to a level of approximately 325 milliosmoles per liter in most instances. A level as high as 338 milliosmoles per liter was reached after combined glucose and urea loading in patient $\mathrm{J}$. F.

In the urine the loading solute accounted for the bulk of the osmolarity. Glucose, when given alone, accounted for $50-60 \%$. During loading with urea and glucose, their combined contribution amounted to as much as $73 \%$. The concentration of the electrolytes decreased with increasing flows regardless of the initial value. The con- centration of sodium in the urine fell sharply to levels of $60-75 \mathrm{mEq}$. per liter in most instances. In the case of urea loading the sodium concentration was more variable. It fell as low as $30 \mathrm{mEq}$. in one test, but was as high as $262.5 \mathrm{mEq}$. in another. Potassium levels in the urine during loading were consistently lower than those of sodium and chloride, and ranged from 12 to $35 \mathrm{mEq}$. per liter in most cases.

\section{Electrolyte losses}

Figures 5 and 6 depict the pattern of electrolyte losses versus flow in the three diabetic subjects. For comparative purposes, the data from two periods of urea loading on a non-diabetic subject have been included. The rates of excretion of sodium, potassium and chloride are plotted against the minute volume of urine.

It can be seen from an inspection of the graphs that the losses of sodium and chloride were almost directly proportional to the urine flow regardless of the loading solute administered. With respect to sodium, the losses increased from a pre-loading value of about 0.085 milliosmole per minute to as high as 1.525 milliosmoles during glucose loading.

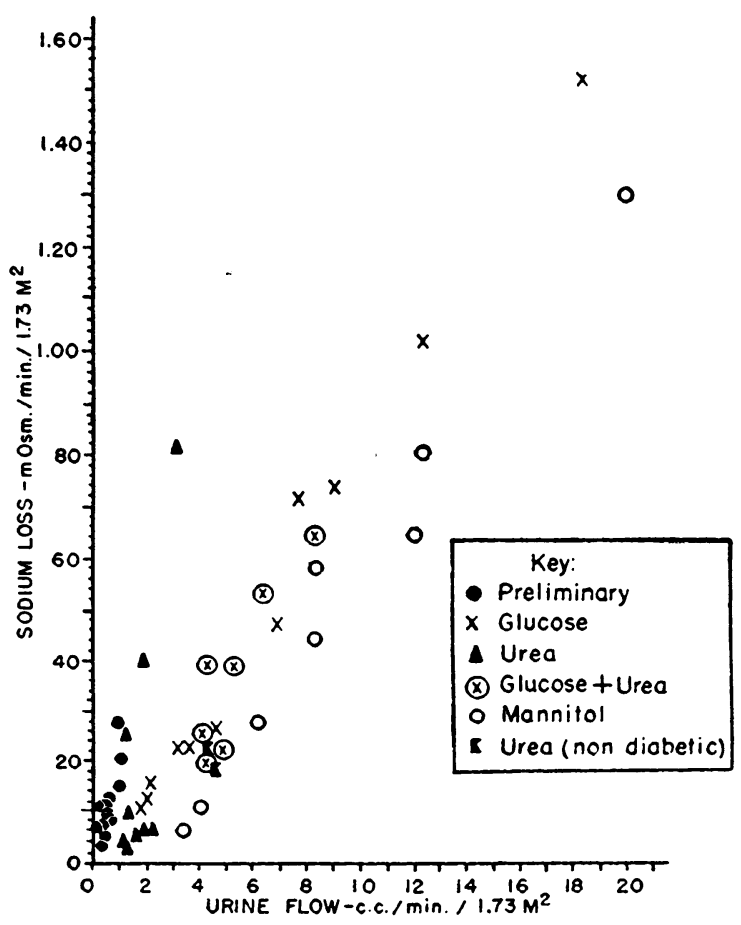

Fig. 5a. Sodium Loss vs. URINe Flow 


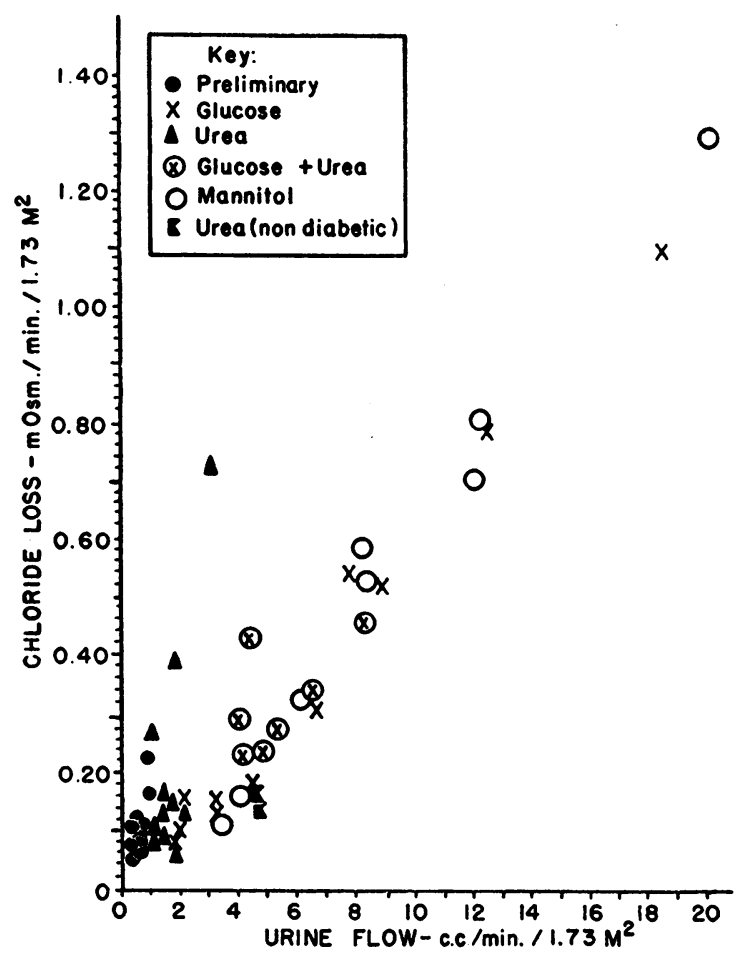

Fig. 5b. Chloride Loss vs. URine Flow

Losses almost as great were attained with mannitol loading.

With urea loading, the sodium and chloride losses increased by as much as eightfold during one loading test while little change was found in another test. In the non-diabetic subject during urea loading, the sodium and chloride losses increased to about twice the control values. The patterns of sodium and chloride excretion in diabetics and non-diabetics were practically identical.

Potassium losses were only slightly increased by solute loading. The small potassium losses and the constant potassium level in the plasma are evidence against significant depletion of intracellular electrolytes during osmotic diuresis. The same pattern of potassium excretion has been found in non-diabetic subjects.

The phosphate losses incurred were similar to those of potassium and are omitted from the presentation.

\section{DISCUSSION}

\section{Conservation of water and electrolytes}

The quantitative reproducibility of the flow-load pattern in all three patients given different loading solutes makes it clear that glycosuric diuresis in the diabetic is a non-specific phenomenon which is not dependent on the chemical or physiological properties of the loading solute. Furthermore, one need not assume differences in the water-binding capacities of the loading solutes to explain differences in diuretic response. The data on the diabetic patients confirm, in all respects, those obtained in non-diabetic subjects with a wide variety of loading solutes.

The reproducibility of the flow-load pattern makes it possible to predict the rate of urine flow if the factors controlling the total load are known.

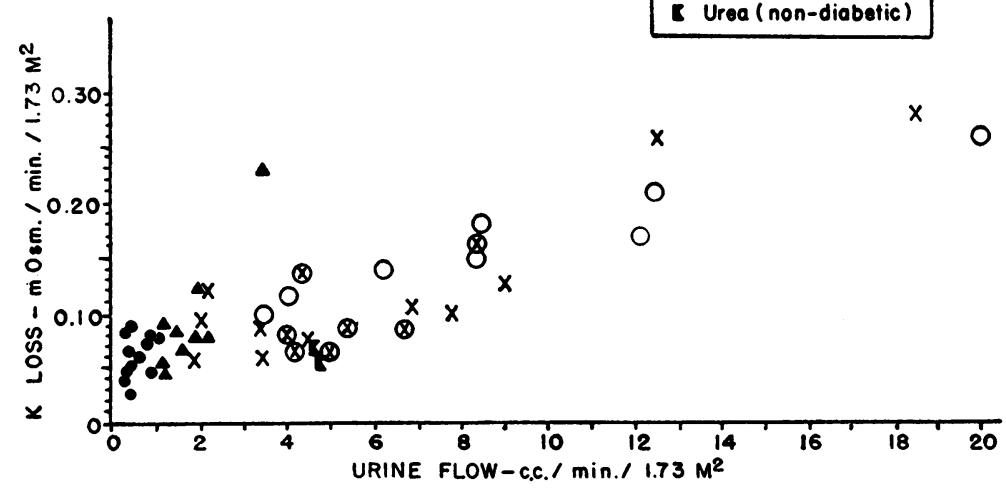

Fig. 6. Potassium Loss vs. Urine Flow 
Given a certain plasma level of any loading solute, the amount reaching the final urine depends only on the intrinsic mode of excretion by the kidney. This may be expressed in general form:

(1) Rate of excretion of loading solute $=\mathrm{P} \times$ GFR - Amount of solute reabsorbed by renal tubule + Amount of solute excreted by renal tubule,

where $P$ is the plasma level and GFR, the glomerular filtration rate. One can predict from the formula what loading solutes will give the largest final urinary load at any given plasma level. In the case of urea, where high plasma levels are obtained, the extensive degree of tubular reabsorption accounts for the low final load and flow. On the other hand, mannitol, at the same plasma level, since it is little reabsorbed, produces a high solute load.

The plasma level of a given loading solute, in general, depends on its volume of distribution, its metabolic fate, and rate of excretion.

During hydropenia without loading, conservation of water and electrolytes is at a maximum. The stress of solute loading results in a pattern of water and electrolyte loss which is reproducible, and represents a load-stress curve which characterizes, over a wide range of urine flows, the water and electrolyte conserving ability of the kidney.

The large electrolyte losses of osmotic loading have obvious clinical implications for the diabetic subject. Two examples from the present study may illustrate the magnitude of the loss of extracellular electrolyte produced by glycosuric diuresis per se.

Patient L. D., after glucose loading by vein, suffered sodium losses at the rate of $1.525 \mathrm{mEq}$. per minute. Had the losses continued at that rate for 24 hours, they would have amounted to a total of $1.525 \times 60 \times 24=2,196 \mathrm{mEq}$. of sodium, or over 16 liters of extracellular fluid. In other words, the entire extracellular compartment would have been depleted. Another patient, J. F., after glucose and urea by mouth, sustained sodium losses at the rate of $0.647 \mathrm{mEq}$. per minute. At this rate of excretion, he would have lost 932 $\mathrm{mEq}$. of sodium or 6.6 liters of extracellular fluid in 24 hours.

The large salt losses serve to explain the degrees of dehydration incurred during prolonged glycosuria and have direct bearing on the fluid therapy of diabetic acidosis. They account for the need of large volumes of saline fluids (5-8).

The constancy of the serum level of potassium during loading together with its low rate of excretion makes it evident that neither increased urine flow nor hyperosmolarity of the plasma did of itself cause appreciable depletion of the intracellular electrolytes. These results are somewhat at variance with the data obtained during the development of diabetic acidosis in man $(3,21)$, which showed losses of sodium that were not so great and were equalled by those of potassium. On the other hand, the results of a study on alloxandiabetic rats which were permitted to lapse into fatal diabetic acidosis (22) showed, if calculated on the basis of body weight, glycosuria and sodium losses which approached those observed in the present study. The potassium losses, however, were almost as large as those of sodium. The explanation of these discrepancies may be sought along several lines. (1) The patients did not have so great a diuresis and glycosuria as was produced in the present study. (2) It is conceivable that had diuresis continued longer in our subjects, the loss of sodium might have decreased, or possibly that of potassium increased. In this connection may be mentioned the observations of several authors (23-28) concerning potassium losses during prolonged dehydration. These losses are of comparatively small magnitude. (3) Probably the most important factor is the effect of the developing acidosis. It is well known that acidosis per se, produced by acidifying salts $(29,30)$ leads to losses of $\mathrm{K}$ and $\mathrm{Na}$ in comparable amounts. In earlier studies (21), the effects of developing acidosis were superimposed on those of glycosuria, a circumstance which did not complicate the present study. (4) It may be hypothesized that ketonemia and changes in the metabolic relations among fat, carbohydrate, and protein may affect the excretion of electrolytes. The possibility of such effects cannot be denied. They have not been sufficiently studied for assessment. Their influence was minimized in the present study by the standard state of the subjects and the short duration of the tests.

Seldin and Tarail, in a recent paper (31) have denied the concept of a relationship between urinary osmolarity and flow. They conclude "that the effects of hypertonic 
solutions on the metabolism and excretion of water and electrolytes are not determined by the osmotic pressure of the tubular urine, but depend instead upon the metabolic and osmotic properties of the administered solute, the character and distribution of the electrolyte, and the previous state of the organism." That the metabolic properties of a given loading solute at a given plasma level do not determine the final urine flow is evident from a comparison of the results of glucose and mannitol loading. Glucose is well metabolized and mannitol is hardly metabolized at all, yet both produce almost the same diuretic response in hydropenia. The rate of metabolic disappearance of a solute is important only insofar as it can reduce the concentration of the solute in the fluid circulating through the kidney. That the volume of distribution of a loading solute does not determine the urine flow is evident from a comparison of the results of mannitol and sodium chloride loading in the paper by Seldin and Tarail as well as others (18). Both solutes are distributed through the extracellular compartment, yet sodium chloride loading, because of extensive tubular reabsorption results in much lower urine flow than mannitol.

The data of Seldin and Tarail merit comment in another respect. Although the subjects were designated as hydropenic, only one had an urinary osmolarity of over 1,000 milliosmoles per liter. The loading solutes were given in concentrations not likely to produce a large osmotic stress. Urea was used in $10 \%$, and glucose, although the subjects were non-diabetic, in $25 \%$ solution. Under such circumstances alterations in the state of hydropenia and discrepancies in the pattern of urinary osmolarity can, and did, occur. (See comment of Seldin and Tarail on their experiment No. 7, p. 167 [31].) Nevertheless, the pattern of urine flow versus total solutes of their experiments closely resembles the curve shown in Figure 2 of the present report.

\section{Exchanges of water and electrolytes}

During solute loading, shifts of water and solutes between the fluid compartments of the body occur. The extracellular fluid is the immediate source of water and electrolytes for the kidney. Intracellular fluid destined for excretion via the kidney must be transferred first to the extracellular compartment, and then transported to the kidney via the circulatory system. The actual shifts observed depend primarily on the diffusibility of the solute injected. Thus, the stages in production of urine water are:

1) intracellular phase $\rightarrow 2$ ) extracellular phase $\rightarrow 3$ ) urine.

An analysis of the body sources of urine water is of great interest for the understanding of the dynamics of water and electrolyte transfers within the body. The most meaningful description of the responses to osmotic loading is obtained when the analysis is based on the condition of the subject before loading. In this way, the contributions of the several fluid compartments during loading may be related to the standard "resting," hydropenic state.

An approximate calculation may be based on the urine volume and the amounts of sodium and potassium excreted according to the principle of the procedure of Gamble and associates (29) and Harrison and associates (32). It is independent of any assumed initial extra- or intracellular volume or of extra-renal losses of water and electrolytes, but is applicable only when the intake of water or of sodium and potassium may be disregarded. Therefore, it cannot be used in loading experiments with sodium or potassium salts.

In these calculations, the amount of water injected with the loading solute is ignored. The use of sodium and potassium as measures of extraand intracellular fluids, respectively, should lead to minor deviations only since the ions account for over $90 \%$ of the cations in each of the phases.

Table II presents an analysis for water losses in the urine with respect to their origin from the fluid compartments of the body. It can be seen

TABLE II

The urine water and its components Apportionment of water losses from the control or 'resting' hydropenic state during osmotic diuresis.

All volumes are expressed as cc. per minute.

\begin{tabular}{l|c|c|c|c|c}
\hline \hline & Period & $\begin{array}{c}\text { Total } \mathrm{H}_{2} \mathrm{O} \\
\text { loss }\end{array}$ & $\begin{array}{c}\text { E.C.F. } \\
\text { loss }\end{array}$ & $\begin{array}{c}\text { I.C. isotonic } \\
\text { fluid loss }\end{array}$ & $\begin{array}{c}\text { I.C. } \text { water } \\
\text { ioss }\end{array}$ \\
\hline J. F. & 2 & 1.41 & 0.67 & 0.57 & 0.17 \\
Urea & 3 & 1.83 & 0.38 & 0.57 & 0.88 \\
& 4 & 2.12 & 0.45 & 0.56 & 1.11 \\
L. D. & 1 & 9.04 & 5.25 & 0.72 & 3.07 \\
Glucose & 3 & 18.5 & 10.8 & 1.66 & 6.04 \\
& 4 & 12.5 & 7.31 & 1.59 & 3.60 \\
J.F. & 8 & 6.70 & 3.80 & 0.44 & 2.46 \\
Glucose & 9 & 5.31 & 2.82 & 0.50 & 1.99 \\
+ Urea & 10 & 8.35 & 4.59 & 0.94 & 2.82 \\
E. H. & 3 & 20.0 & 9.22 & 1.59 & 9.21 \\
Mannitol & 4 & 12.4 & 5.72 & 1.32 & 5.36 \\
& 5 & 8.45 & 3.14 & 1.20 & 4.11 \\
\hline
\end{tabular}

The calculations were made on the basis of an assumed initial sodium level of $141 \mathrm{mEq}$. per liter of extracellular water, and an assumed potassium level of $143 \mathrm{mEq}$. per liter of cell water (32). 
that the losses of extracellular fluid, on the whole, paralleled the urine flow, as would be expected from the pattern of sodium and chloride losses with respect to urine flow. The amount of isotonic or solute-containing fluid leaving the cells changed only little. A tendency to a slight increase at high rates of urine flow is apparent. The volume of water alone leaving the cells varied with the loading solutes employed, and appeared to bear a relation to their diffusibility. With urea, only small amounts of water left the cells, even at the highest plasma levels. With glucose loading, considerable amounts of water alone migrated from the cells and accounted for about $30 \%$ of the total urine water lost. With mannitol, which is confined to the extracellular fluid and minimally metabolized, the greatest transfer of cell water occurred. The intracellular water accounted for almost $50 \%$ of the total water loss, and exceeded even the contribution of the extracellular phase. Similar changes have been described by others (31) using a different method of calculation.

Finally the dynamics of fluid movements may be considered from the post-loading state of the individual when shifts occasioned by the injection of the loading solute have already taken place. Since the osmolarity of the urine is higher than that of the body fluid, a water economy will result. It can be expressed as follows :

$$
\mathrm{H}_{2} \mathrm{O}_{\mathrm{EC}}=\frac{\text { Load }}{\mathrm{B}}-\text { Urine volume, }
$$

where $\mathrm{H}_{2} \mathrm{O}_{\mathrm{EC}}$ represents the water economized, load, the total number of osmols excreted, and $\mathrm{B}$ the osmolarity of the body fluids. The value of $\frac{\text { Load }}{\mathrm{B}}$ signifies the volume of isotonic body fluid cleared by the kidney. As the body clears itself of the loading solute, water drawn from the intracellular phase returns to the cells from the glomerular filtrate via the extracellular fluid. Thus, the water movement proceeds in the direction,

1) glomerular filtrate $\rightarrow 2$ ) extracellular phase $\rightarrow 3$ ) intracellular phase.

The water economized distributes itself among the respective fluid compartments of the body in inverse ratio to the percentage of solute lost.

The amount of water economized versus time provides an estimate of the course of return to an equilibrium state of the body with minimal urine flows. The intensity of water economy, i.e., the amount conserved per cc. of urine excreted, is greater, the higher the osmolarity of the urine. The final equilibrium state differs from the preloading state to the extent of the losses of body water and electrolytes incurred during the osmotic diuresis.

\section{SUM MARY}

The mechanism of glycosuric diuresis in diabetic man during the hydropenic state has been studied. The loading solutes were glucose, urea, and mannitol administered in amounts of 400 1,100 milliosmoles per 1.73 square meters of body surface.

A reproducible relationship between urine flow and concentration or load was found independent of the chemical or metabolic characteristics of the loading solute. The pattern of urine flow and load is identical to that of non-diabetic subjects during osmotic diuresis. Therefore, it is concluded that glucose diuresis in the diabetic subject is a non-specific phenomenon depending only on the total number of osmotically active particles being excreted and not on a specific effect of glucose.

The calculated ideal osmotic work followed a pattern identical in nature to that seen in osmotic diuresis of non-diabetic subjects. It increased to a maximum value of about $4.0 \mathrm{gm}$. cal. per minute, and was not potentiated by further increases in urine flow, load or plasma level of the loading solute.

With regard to electrolyte losses, it was found that loss of sodium and chloride increased sharply during diuresis in almost direct proportionality to the rate of urine flow. Potassium and phosphate losses increased only to a small extent with great increases in urine flow. The clinical implications of these losses have been discussed.

The sources of urinary water and the transfers of water and electrolytes among the fluid compartments of the body have been discussed.

\section{BIBLIOGRAPHY}

1. Cushny, A. R., The Secretion of the Urine. Longmans-Green, London, 1917.

2. Hendrix, B. M., Fay, M., Calvin, D. B., and Bodansky, M., The effect of excretion of acids and 
bases upon the development of acidosis in experimental diabetes. J. Biol. Chem., 1926, 69, 449.

3. Atchley, D. W., Loeb, R. F., Richards, D. W., Jr., Benedict, E. M., and Driscoll, M. E., On diabetic acidosis. A detailed study of electrolyte balances following the withdrawal and reestablishment of insulin therapy. J. Clin. Invest., 1933, 12, 297.

4. Peters, J. P., Bulger, H. A., Eisenman, A. J., and Lee, C., Total acid-base equilibrium of plasma in health and disease. VI. Studies of diabetes. J. Clin. Invest., 1925, 2, 167.

5. Fitz, R., Observations on kidney function in diabetes mellitus. Arch. Int. Med., 1917, 20, 809.

6. Beard, A. H., Salt metabolism in diabetes mellitus. Arch. Int. Med., 1918, 21, 716.

7. Wilder, R. M., and Beeler, C., Plasma chlorides and edema in diabetes. Am. J. Physiol., 1921, 55, 287.

8. Blum, L., Grabar, P., and Van Caulaert, L'azotémie par manque de sel dans la diabète grave. Ann. de méd., 1929, 25, 23. L'azotémie par manque de sel. Son mécanisme. Ibid., 1929, 25, 34.

9. McCance, R. A., and Lawrence, R. D., The secretion of urine in diabetic coma. Quart. J. Med., 1935, 4, 53.

10. McCance, R. A., and Widdowson, E. M., Functional disorganization of the kidney in disease. J. Physiol., 1939, 95, 36.

11. Moutard-Martin, R., and Richet, C., Recherches expérimentales sur la polyurie. Arch. de physiol. norm. et path., 2nd series, 1881, 8, 1.

12. Hédon, E., and Arrous, J., Des relations existant entre les actions diurétiques et les propriétés osmotiques des sucres. Compt. rend. Soc. de biol., 10th series, 1899, 6, 884.

13. Arrous, J., Etude comparative de l'action diurétique des sucres. Coefficient diurétique. Compt. rend. Soc. de biol., 10th series, 1899, 6, 879.

14. Starling, E. H., The glomerular functions of the kidney. J. Physiol., 1899, 24, 317.

15. Conway, E. J., The relation in diuresis between volume of urine and the concentration of a diuretic with the influence of temperature upon it. J. Physiol., 1925, 60, 30.

16. Hervey, G. R., McCance, R. A., and Tayler, R. G. O., Forced diuresis during hydropenia. Nature, 1946, 157, 338.

17. Hervey, G. R., McCance, R. A., and Tayler, R. G. O., Further observations on the causes of a diuresis during hydropenia. J. Physiol., 1946, 104, 43P.

18. Rapoport, S., Brodsky, W. A., West, C. D., and Mackler, B., Urinary flow and excretion of solutes during osmotic diuresis in hydropenic man. Am. J. Physiol., 1949, 156, 433.

19. Rapoport, S., Brodsky, W. A., and West, C. D., Excretion of solutes and osmotic work of the "resting" kidney of hydropenic man. Am. J. Physiol., 1949, 157, 357.

20. Rapoport, S., West, C. D., and Brodsky, W. A., Excretion of solutes and osmotic work during osmotic diuresis of hydropenic man. The ideal and the proximal and distal tubular work; the biological maximum of work. Am. J. Physiol., 1949, 157, 363.

21. Butler, A. M., Talbot, N. B., Burnett, C. H., Stanbury, J. B., and MacLachlan, E. A., Metabolic studies in diabetic coma. Tr. A. Am. Physicians, 1947, 60, 102.

22. Brodsky, W. A., Nelson, N., and Guest, G. M., Mineral metabolism in rats with alloxan-induced diabetes. Am. J. Dis. Child., 1949, 77, 133.

23. Wiley, F. H., and Wiley, L. L., The inorganic salt balance during dehydration and recovery. J. Biol. Chem., 1933, 101, 83.

24. Kerpel-Fronius, E., Uber die Beziehungen zwischen Salz- und Wasserhaushalt bei experimentellen Wasserverlusten. Ztschr. f. Kinderh., 1935, 57, 489.

25. Nadal, J. W., Pedersen, S., and Maddock, W. G., A comparison between dehydration from salt loss and from water deprivation. J. Clin. Invest., 1941, 20, 691.

26. Elkinton, J. R., and Taffel, M., Prolonged water deprivation in the dog. J. Clin. Invest., 1942, 21, 787.

27. Black, D. A. K., McCance, R. A., and Young, W. F., A study of dehydration by means of balance experiments. J. Physiol., 1944, 102, 406.

28. McCance, R. A., Young, W. F., and Black, D. A. K., The secretion of urine during dehydration and rehydration. J. Physiol., 1944, 102, 415.

29. Gamble, J. L., Blackfan, K. D., and Hamilton, B., A study of the diuretic action of acid producing salts. J. Clin. Invest., 1924, 1, 359.

30. Dennig, H., Dill, D. B., and Talbott, J. H., Bilanzuntersuchung einer Salmiakazidose. Arch. $f$. exper. Path. u. Pharmakol., 1929, 144, 297.

31. Seldin, D. W., and Tarail, R., Effect of hypertonic solutions on metabolism and excretion of electrolytes. Am. J. Physiol., 1949, 159, 160.

32. Harrison, H. E., Darrow, D. C., and Yannet, H., The total electrolyte content of animals and its probable relation to the distribution of body water. J. Biol. Chem., 1936, 113, 515. 